Gut, 1974, 15, 953-959

\title{
Indices of granulocyte activity in inflammatory bowel disease
}

\author{
S. P. KANE ${ }^{1}$, A. V. HOFFBRAND, AND G. NEALE \\ From the Departments of Medicine and Haematology, Royal Postgraduate Medical School, London
}

SUMMARY In conditions with increased neutrophil production, the serum total vitamin $\mathrm{B}_{12}$-binding capacity (TBBC) is considered to correlate with the blood pool size of neutrophil granulocytes. The serum lysozyme, on the other hand, is a measure of neutrophil (and monocyte) turnover. The mean serum TBBC was significantly raised in patients with ulcerative colitis (range $1 \cdot 23-5 \cdot 51$ $\mathrm{ng} / \mathrm{ml}$; mean $2.64 \mathrm{ng} / \mathrm{ml}$ ) and patients with Crohn's disease (range $1.58-9.29 \mathrm{ng} / \mathrm{ml}$; mean $2.93 \mathrm{ng} / \mathrm{ml}$ ). The elevated values were shown to be due to rises in the granulocyte-secreted binding proteins, transcobalamins I and III. The TBBC was shown to rise with increasing activity of disease and to correlate roughly with the blood neutrophil granulocyte count. Patients with inflammatory bowel disease also had a significantly raised mean level of serum lysozyme (range 3.1 to $10.4 \mu \mathrm{g} / \mathrm{ml}$; mean $6.8 \mu \mathrm{g} / \mathrm{ml}$ ), but there was no correlation in individual patients between serum lysozyme and total $\mathrm{B}_{12}$-binding capacity. These results are taken to indicate an enlarged granulocyte pool and increased granulocyte turnover in inflammatory bowel disease.

Although it is known that granulocytes cross the mucosa and enter the lumen of the intestine in large numbers in patients with inflammatory bowel disease (Anthonisen and Riis, 1962; Riis and Anthonisen, 1971) their role in the pathological process has received little attention, perhaps because lymphocytes, plasma cells, and histocytes predominate in diseased tissue. Markedly increased numbers of neutrophil leucocytes are rarely found in the circulation of patients with ulcerative colitis or Crohn's disease but they are always present in excess in the inflamed bowel, and crypt abscesses occur frequently in acute ulcerative colitis. In inflammatory conditions, increased granulocyte activity may be associated with high levels of circulating vitamin $\mathrm{B}_{12}$-binding proteins, which rarely lead to elevated serum levels of vitamin $\mathbf{B}_{12}$ (Carmel, 1972a). That a similar situation might exist in patients with inflammatory bowel disease was suggested by our finding of a high serum concentration of vitamin $B_{12}$ in a patient with ulcerative colitis (serum vitamin $B_{12}-2400 \mathrm{pg} / \mathrm{ml}$ ). Repeated studies in this patient showed a high serum unsaturated vitamin $B_{12}$-binding capacity ranging from $4 \cdot 2$

${ }^{1}$ Reprint requests to Dr S. P. Kane, Royal Postgraduate Medical School, London, W12 OHS, United Kingdom.

Received for publication 16 August 1974. to $5.9 \mathrm{ng} / \mathrm{ml}$ (normal range: $0.8-1.7 \mathrm{ng} / \mathrm{ml}$ ). The patient also had a high concentration of serum lysozyme, an enzyme which has been used as a measure of granulocyte turnover (Hansen, 1973). Taken together these findings suggested excess granulocytic activity even though the patient's blood neutrophil granulocyte counts were never excessively high $\left(7000-12000 / \mathrm{cmm}^{3}\right)$.

In this paper we report a prospective study of vitamin $\mathbf{B}_{12}$-binding proteins and serum lysozyme in an unselected group of patients with inflammatory bowel disease. The study was designed to determine the incidence of high serum levels of vitamin $B_{12-}$ binding proteins and of lysozyme in such patients and to correlate these indices of granulocyte activity with previously established markers of active inflammation.

\section{Patients Studied}

\section{PATIENTS WITH INFLAMMATORY BOWEL DISEASES}

The study was performed on 23 patients with ulcerative colitis and 26 patients with Crohn's disease who were seen consecutively at Hammersmith Hospital by one of us (S.K.). The index case is not included in the results of the prospective study. The diagnosis of inflammatory bowel disease was established on the 
basis of the usual clinical, radiological, and histological criteria. Most patients were studied while on treatment with sulphasalazine, local or systemic steroids, or azathioprine. The ages of the patients ranged from 18 to 84 years. Disease activity was divided arbitrarily into four grades: (I) complete absence of symptoms and physical signs; (II) mild disease controlled on an outpatient basis; (III) moderate illness requiring inpatient care; (IV) severe illness with gross systemic upset and incapacitating diarrhoea.

\section{CONTROL SUBJECTS}

Three groups were used: (1) 12 healthy members of the medical and laboratory staff, aged between 18 and 42 years; (2) 17 patients aged $20-72$ years, with diarrhoea and abdominal pain shown not to be due to ulcerative colitis or Crohn's disease. (Nine of these patients had the irritable bowel syndrome, four had diverticular disease, two had coeliac disease, one had a salmonellar enteritis, and one had a duodenal diverticulum.) (3) Ten patients aged 18-64 years with active rheumatoid arthritis.

\section{Materials and Methods}

Circulating serum vitamin $\mathbf{B}_{12}$ is bound to three trace transport proteins, transcobalamins (TC) I, II, and III, the properties, origins, and significance of which have recently been reviewed (Zittoun and Zittoun, 1973). Their capacity to bind an excess of added vitamin $\mathrm{B}_{12}$ in vitro is expressed as the serum unsaturated vitamin $B_{12}$-binding capacity (UBBC). The sum of the $U B B C$ and the serum vitamin $B_{12}$, the total $\mathrm{B}_{12}$-binding capacity or $\mathrm{TBBC}$, reflects the sum of the serum transcobalamins. In seven patients with raised TBBC values, the relative contributions of the individual transcobalamins were assessed. For these studies serum was separated from samples of venous blood within two hours of venesection and stored at $-20^{\circ} \mathrm{C}$ until the time of assay.

SERUM VITAMIN B 12

Vitamin $B_{12}$ was assayed microbiologically, using the ' $\mathrm{z}$ ' strain of Euglena gracilis (Anderson, 1964) (normal range 160-925 pg/ml).

SERUM UNSATURATED B12-BINDING CAPACITY (U B B C)

The serum UBBC was estimated by a modification of the rapid charcoal assay originally described by Gottlieb, Lau, Wasserman, and Herbert (1965). One $\mathrm{ml}$ of a solution of ${ }^{57} \mathrm{Co}-\mathrm{B}_{12}$ (Radiochemical Centre, Amersham) containing $2400 \mathrm{pg}$ vitamin $B_{12}$ was added to $0.5 \mathrm{ml}$ of test serum. The mixture was incubated for $30 \mathrm{~min}$ at room temperature, and excess free vitamin $B_{12}$ was removed by incubating for $10 \mathrm{~min}$ with a $2 \mathrm{ml}$ suspension of albumin-coated charcoal (prepared by mixing equal volumes of a $1 \%$ solution of bovine serum albumin and a $5 \%$ aqueous suspension of Norit A charcoal). After incubation, the suspension was centrifuged for $10 \mathrm{~min}$ at 3000 $\mathrm{rpm}$ and $2 \mathrm{ml}$ of the supernatant was counted against a standard in an automatic gamma counter (Hewlett Packard). The results were expressed in ng $B_{12}$ bound $/ \mathrm{ml}$ test serum.

SEPARATION OF SERUM B12-BINDING PROTEINS The high molecular weight, granulocyte-secreted binding proteins TC I and TC III were separated from the lower molecular weight protein (TC II) by gel filtration using Sephadex G200 (Pharmacia) under conditions similar to those described by Bloomfield and Scott (1972). Serum of known UBBC, $0.25-1.0 \mathrm{ml}$, was incubated for $30 \mathrm{~min}$ at room temperature with enough ${ }^{57} \mathrm{Co}-\mathrm{B}_{12}$ (made up as a solution containing $2400 \mathrm{pg}$ vitamin $\mathrm{B}_{12} / \mathrm{ml}$ ) to saturate fully the binding capacity. The mixture was then layered onto a Sephadex column (dimensions $60 \mathrm{~cm} \times 4 \mathrm{sq} \mathrm{cm}$ ) and $504 \mathrm{ml}$ fractions were eluted with $0.04 \mathrm{M}$ phosphate in $0.5 \mathrm{M} \mathrm{NaCl}$ (containing sodium azide $0.001 \%$ as a preservative) at the rate of one fraction every 45 minutes. The radioactivity of the fractions was determined in an automatic gamma counter and compared with a known standard. Thus the binding capacity of each fraction could be calculated. Transcobalamins I and III were eluted maximally between fractions 24 and 28, and TC II between fractions 34 and 38. Excess free vitamin $B_{12}$ appeared as a separate peak around fraction 46.

The batch separation technique of Silverstein and Herbert (1968) was used to separate unsaturated TC I from unsaturated TC II and TC III. Serum, $0 \cdot 25 \mathrm{ml}$, was incubated for $30 \mathrm{~min}$ with $0.25 \mathrm{ml}$ of a ${ }^{57} \mathrm{Co}-\mathrm{B}_{12}$ solution containing $12 \mathrm{ng}$ vitamin $\mathrm{B}_{12} / \mathrm{ml}$. This was then mixed with 0:5 ml albumin-coated charcoal suspension prepared as described above. After standing for 10 minutes the mixture was centrifuged for 10 minutes at $3000 \mathrm{rpm}$. The supernatant was decanted and mixed with $170 \mathrm{mg}$ untreated DE 23 cellulose (Whatman) and $2 \mathrm{ml} 0.02 \mathrm{M}$ sodium phosphate buffer, $\mathrm{pH} 6 \cdot 3$. The mixture was allowed to stand for 10 minutes after which $5 \mathrm{ml}$ of $0.06 \mathrm{M}$ sodium phosphate buffer, $\mathrm{pH} 6 \cdot 3$, was added. The centrifuge tube was inverted intermittently for 10 min and centrifuged for $10 \mathrm{~min}$ at $3000 \mathrm{rpm}$. The supernatant was decanted, and a further $5 \mathrm{ml}$ of $0.06 \mathrm{M}$ phosphate buffer was added followed by further mixing and centifugation. The two supernatants, containing the binders eluted at low ionic strength (TC II and TC III), and the DE 23 pre- 
cipitate containing TC I, were counted with a ${ }^{57} \mathrm{Co}-\mathrm{B}_{12}$ standard in an automatic gamma counter.

\section{SERUM LYSOZYME}

Serum lysozyme (muramidase) was assayed by the turbidimetric method of Parry, Chandan, and Shahani (1965). In this assay, the rate of decrease of optical density at $37^{\circ} \mathrm{C}$ of a $2.5 \mathrm{ml}$ suspension of $250 \mu \mathrm{g} / \mathrm{ml}$ UV killed Micrococcus leisodeikticus (Difco) in $0.067 \mathrm{M}$ potassium phosphate buffer, $\mathrm{pH}$ 6.2 , was measured at $450 \mathrm{~nm}$ after adding $0.1 \mathrm{ml}$ of serum. Results were calculated by reference to a standard curve, obtained by assaying graded concentrations of egg-white lysozyme (Sigma).

HAEMOGLOBIN, GRANULOCYTE COUNT, ESR, SERUM ALBUMIN

These estimations were performed using standard haematological and biochemical techniques.

\section{Results}

\section{SER UM VITAMIN B12}

The normal controls had a mean serum vitamin $\mathbf{B}_{12}$ level of $423 \mathrm{pg} / \mathrm{ml}$ (range 160 to $688 \mathrm{pg} / \mathrm{ml}$ ) whereas the 49 patients with inflammatory bowel diseases had a mean level of $462 \mathrm{pg} / \mathrm{ml}$ (range 104-2200 pg/ml). $T h \in$ difference between these two mean levels was not significant $(t=0.6 ; P>0.5)$ nor was there a significant difference in levels between the patients with ulcerative colitis and those with Crohn's disease. Two patients had serum vitamin $\mathbf{B}_{12}$ levels well outside the normal range at 1600 and $2200 \mathrm{pg} / \mathrm{ml}$ and only one of the patients had a serum vitamin $B_{12}$ level below $160 \mathrm{pg} / \mathrm{ml}$.

\section{SERUM TOTAL B12-BINDING CAPACITY}

The 49 patients with inflammatory bowel diseases had a mean TBBC of $2.85 \mathrm{ng} / \mathrm{ml}$, while the mean value in the 12 normal subjects was $1.66 \mathrm{ng} / \mathrm{ml}$ (fig 1). This difference was highly significant $(t=5.2 ; \quad P<0.001)$. There was no significant difference between the mean TBBC of normal controls and that of patients with either noninflammatory bowel diseases or with rheumatoid arthritis. There was no significant difference in TBBC between 23 patients with ulcerative colitis (mean $2.64 \mathrm{ng} / \mathrm{ml}$ ) and 26 patients with Crohn's disease $($ mean $2.93 \mathrm{ng} / \mathrm{ml})(\mathrm{t}=0.77 ; \mathrm{P}>0.4)$.

\section{CONTRIBUTIONS OF THE INDIVIDUAL}

TRANSCOBALAMINS TO THE RAISED TBBC

Sera from seven patients with a TBBC of greater than $2.8 \mathrm{ng} / \mathrm{ml}$ were fractionated using Sephadex G200, and evaluated by DE 23-cellulose batch separation. The results are shown in the table together with the

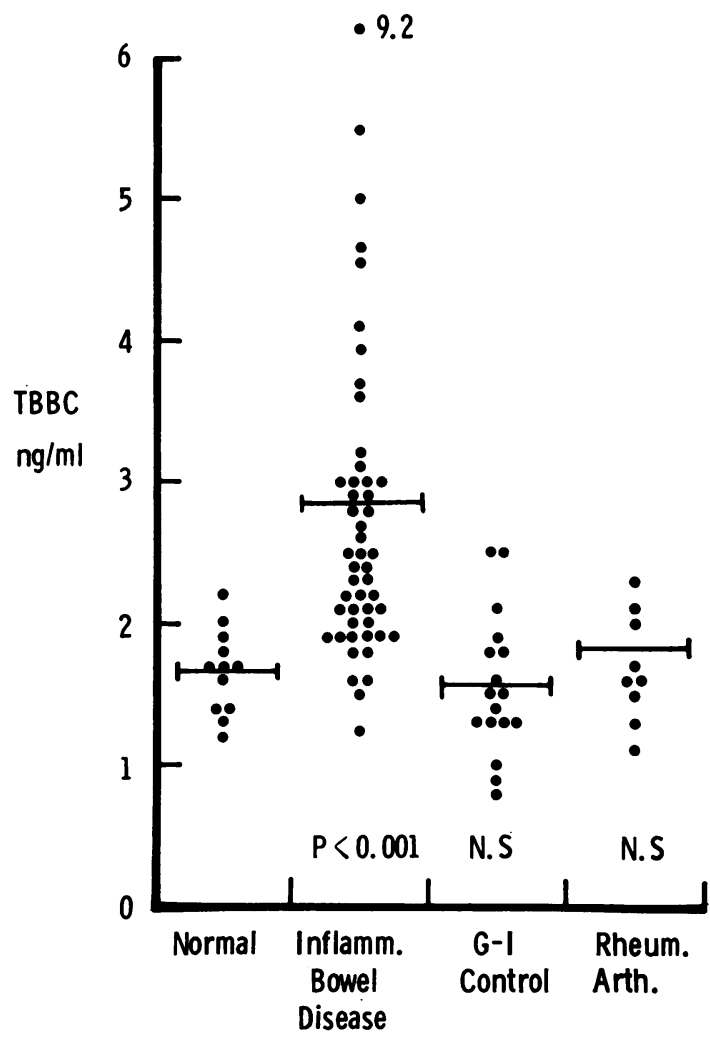

Fig 1 Serum TBBC in $\mathrm{ng} / \mathrm{ml}$ in 12 normal subjects, 49 patients with inflammatory bowel disease, 17 patients with other bowel diseases, and 10 patients with rheumatoid arthritis.

\begin{tabular}{llllll}
\hline Patients & $\begin{array}{l}\text { UBBC } \\
(n g / m l)\end{array}$ & \multicolumn{5}{l}{ Transcobalamin $(\mathrm{ng} / \mathrm{ml})$} \\
\cline { 3 - 6 } & & $I I$ & $I+I I I$ & $I$ & $I I I$ \\
\hline B.B. & 1.39 & 0.89 & 0.50 & & \\
M.A. & 1.47 & 0.60 & 0.87 & & \\
P.G. & 1.68 & 1.30 & 0.38 & & \\
S.H. & 2.41 & 1.13 & 1.28 & 0.89 & 0.39 \\
R.H. & 2.84 & 1.14 & 1.70 & 0.71 & 0.99 \\
P.P. (Relapse) & 3.38 & 1.50 & 1.88 & 0.71 & 1.17 \\
P.P. (Remission) & 1.45 & 1.10 & 0.35 & & \\
K.H. & 3.70 & 1.94 & 1.76 & 1.15 & 0.61 \\
M.B. & 4.08 & 1.16 & 2.92 & 2.17 & 0.75 \\
A.L. & 5.26 & 1.61 & 3.65 & 2.00 & 1.65 \\
E.C. & 9.02 & 1.03 & 7.99 & 1.44 & 6.55 \\
Normal values & $0.93-1.70$ & $0.33-1.15$ & $0.11-0.62$ & $0.03-0.18$ & $0.08-0.44$
\end{tabular}

Table Serum unsaturated vitamin $B_{12}$-binding capacities $(U B B C)$ and unsaturated binding capacities of transcobalamins (TC) I, II and III in 10 patients with inflammatory bowel disease

1The normal range for UBBC is from the present study whilst the ranges of unsaturated binding capacities for the individual transcobalamins is from Bloomfield, Scott, Somerville, and Weir (1973). (Their range for serum UBBC was $0 \cdot 62-1 \cdot 34 \mathrm{ng} / \mathrm{ml}$.) 


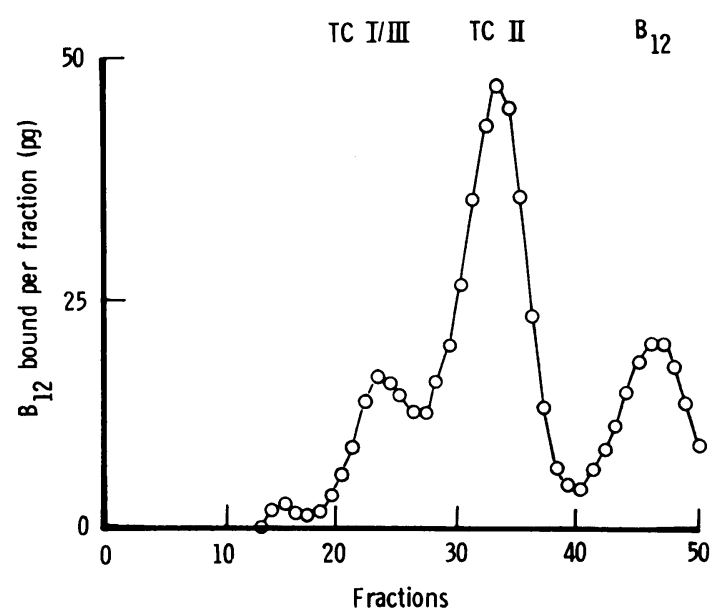

Fig 2 Sephadex 6200 fractionation of $0.5 \mathrm{ml}$ of serum from patient (P.G.) with Crohn's disease (UBBC $1.68 \mathrm{ng} / \mathrm{ml}$ ), showing the separate peaks of TC IIIII, TC II, and free ${ }^{57} \mathrm{Co}-B_{12}$.

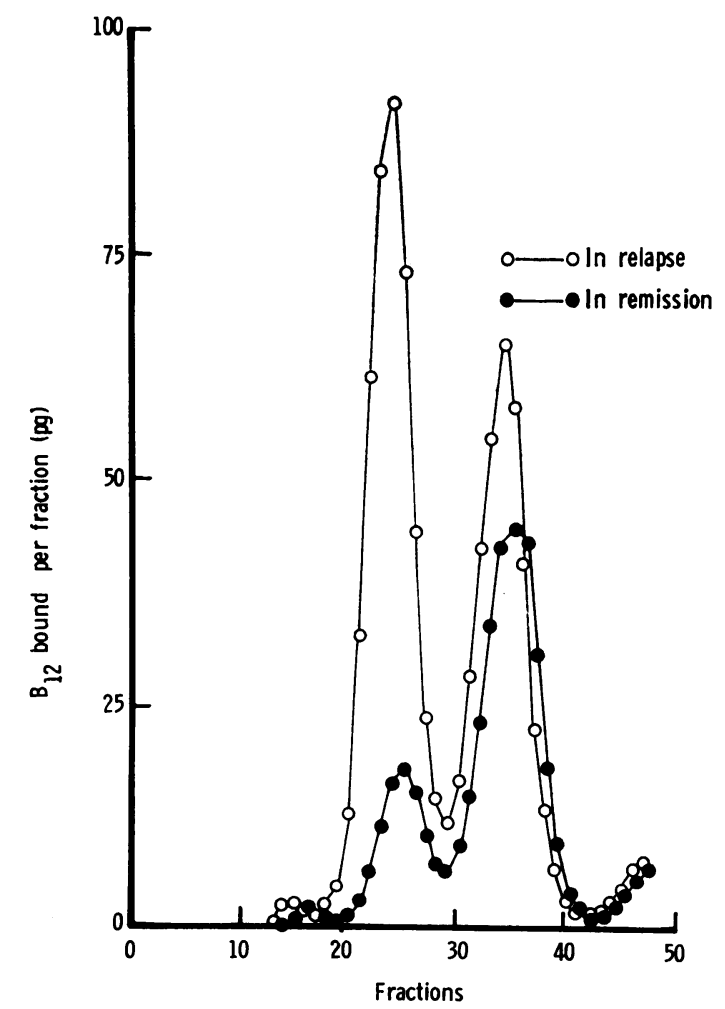

Fig 3 Sephadex G200 fractionation of $0.5 \mathrm{ml}$ of serum from patient (P.P.) with ulcerative colitis in relapse (UBBC $3.38 \mathrm{ng} / \mathrm{ml}$ ) and in remission (UBBC $1.45 \mathrm{ng} / \mathrm{ml}$ ).
Sephadex G200 fractionation of the sera of three patients whose TBBCs were in the normal range. Representative gel filtration curves are shown in figures 2 and 3. The rise in UBBC and hence in TBBC in patients with inflammatory bowel disease appears to be due largely to a rise in the granulocytesecreted binders, TC I and TC III, with no significant rise in transcobalamin II. This is exemplified by the study of one patient before and after a remission (fig 3).

CORRELATION OF TBBC WITH DISEASE ACTIVITY Mean values of TBBC increase progressively with disease activity. Asymptomatic patients (grade I) had TBBC levels which did not differ from control values (fig 4). Grade II patients had significantly raised

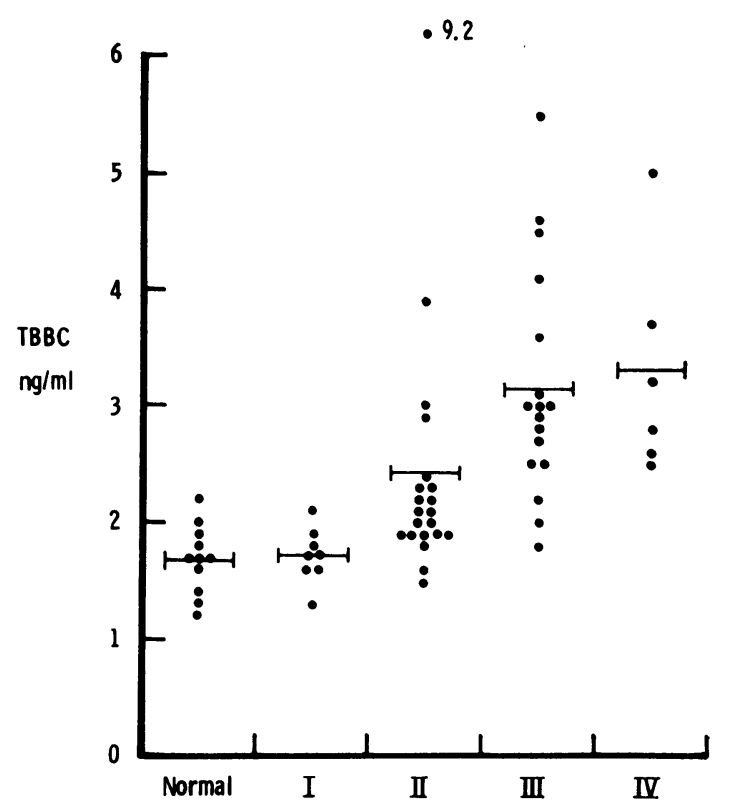

Fig 4 Serum $T B B C$ in $n g / m l$ in 49 patients with inflammatory bowel disease, six of whom were restudied in remission. Patients were graded I-IV according to clinical severity, and TBBCs contrasted with TBBCs in 12 normal subjects.

levels compared with grade I patients $(0.05>\mathrm{P}>$ 0.01 ). The differences between grade II and grade III, and between grade III and grade IV were not statistically significant, but patients with grade III and IV disease together had significantly higher values than those with grade II disease $(0.05>$ P $>$ $0.01)$. Moreover, in seven patients studied before and after treatment (fig 5), there was a significant fall in TBBC as the disease remitted $(0.02>P>0.01)$. 


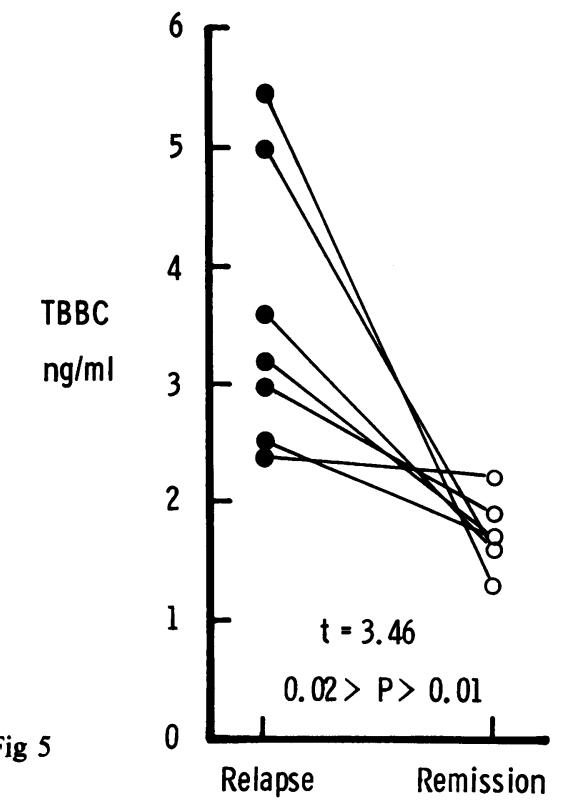

Fig 5 Serum $T B B C$ in seven patients with inflammatory bowel disease studied in relapse and in subsequent remission.

Fig 6 Serum lysozyme values in 12 normal subjects and 21 patients with inflammatory bowel disease.

Correlations were sought between TBBC and recognized indices of disease activity in the patients with inflammatory bowel diseases, but no correlation could be found with haemoglobin concentration ( $\mathrm{n}=29, \mathrm{r}=0.03, \mathrm{P}>0.05)$, serum albumin $(\mathrm{n}=20$, $r=0.33, \quad P>0.05)$, or ESR $(n=26, r=0 \cdot 1$, $P>0.05$ ). There was, however, a just significant correlation between TBBC and circulating granulocyte count $(n=27, r=0.4, P=0.05)$.

\section{SERUM LYSOZYME}

The mean serum lysozyme value in 21 patients with inflammatory bowel disease, $6.8 \mu \mathrm{g} / \mathrm{ml}$, was significantly greater than the mean value of $5.1 \mu \mathrm{g} / \mathrm{ml}$ in 12 normal subjects $(0.01>P>0.001)$ (fig 6). There was no correlation between serum lysozoyme levels and TBBC measured on the same sera $(n=21$, $r=0.30, P>0.05$ ).

\section{AN ATYPICAL B12-BINDING PROTEIN IN A FATHER AND DAUGHTER WITH ULCERATIVE COLITIS}

A man with longstanding but inactive ulcerative colitis, not included in the above groups, was noted to have very high levels of TBBC $(12 \cdot 0,14.8,27 \cdot 8$ $\mathrm{ng} / \mathrm{ml}$ ) on three occasions in eight months. This rise

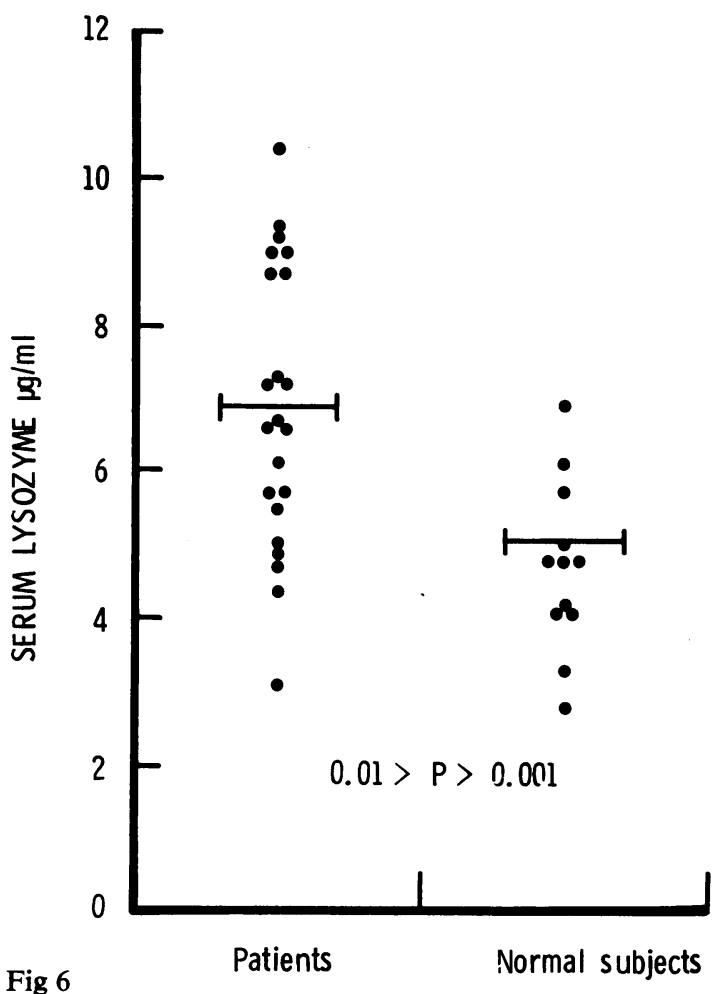

was entirely due to gross elevation of transcobalamin II. Levels of TC I and TC III were normal as judged by Sephadex G-200 gel filtration. The patient's daughter, also with longstanding but quiescent colitis, had TBBC values of $3 \cdot 7,3 \cdot 7$, and $3.4 \mathrm{ng} / \mathrm{ml}$. Once again, the rise was due to TC II alone. The cause of these changes, which do not appear to be related to the patients' inflammatory bowel disease, is unknown. Further studies on the nature of their $B_{12}$-binding proteins will be reported in detail elsewhere (Kane, Hoffbrand, and Neale, 1974, in preparation).

\section{Discussion}

These results show that patients with inflammatory bowel disease frequently have raised levels of total serum vitamin $\mathrm{B}_{12}$-binding capacity due primarily to increased concentrations of transcobalamins $I$ and III. While TBBC correlates to some extent with disease activity, rising with increasing severity of illness and falling with remission of disease, it correlates poorly with other established indices of disease activity. 
The relationship between raised levels of serum vitamin $B_{12}$, raised $U B B C$, and the myeloproliferative disorders (in particular chronic granulocytic leukaemia) has long been recognized (Herbert, 1968; Catovsky, Galton, Griffin, Hoffbrand, and Szur, 1971). These rises were considered to derive largely from increased circulating levels of the $\alpha$-globulin binder, transcobalamin I. However, in more recent studies it has been shown that TC III also contributes to the raised UBBC levels in chronic granulocytic leukaemia (Bloomfield, Scott, Somerville, and Weir, 1973), and it constitutes the major component of the elevated UBBC found in states of chronic granulocytosis and granulocyte flux (Carmel, 1972a and b). These findings accord with the evidence that both of these vitamin $B_{12}$-binding proteins are actively secreted by mature granulocytes (Corcino, Krauss, Waxman, and Herbert, 1970; Carmel and Herbert, 1972). Moreover, Chikkappa, Corcino, Greenberg, and Herbert (1971) have shown an excellent correlation between total blood granulocyte pool, measured in vivo by an isotope dilution technique, and both UBBC and total $\mathrm{B}_{12}$-binding capacity. They concluded that measurement of the UBBC may be employed as a simple way of assessing the total blood granulocyte pool. The circulating granulocyte count is dependent upon the distribution of granulocytes and between the circulating marginating components of the pool, and is therefore an unreliable guide to the size of the total pool. Carmel (1972a), while finding increased UBBCs in patients with leucocytosis, found little direct correlation between neutrophil granulocyte counts and UBBC levels. In patients with inflammatory bowel disease, there is only a weak correlation. In chronic granulocytic leukaemia, on the other hand, there is a good correlation between granulocyte counts and TBBC (Catovsky et al, 1971). It seems that many patients with inflammatory bowel disease, particularly those with more active disease, have an expanded body pool of granulocytes, a feature which is not found in a miscellaneous collection of other bowel diseases, nor in rheumatoid arthritis, a chronic inflammatory process not involving the bowel. The site of this pool is, therefore, likely to be the bowel wall itself.

The serum vitamin $\mathbf{B}_{12}$ was normal in nearly all of our patients. This is similar to the finding of Carmel (1972a) in patients with benign granulocytosis and a raised TBBC, and contrasts with the usual finding in myeloproliferative diseases in which the serum vitamin $B_{12}$ itself is often raised. The explanation for the difference is uncertain, but it may be that the increased TBBC in inflammation is predominantly in TC III and not in TC I as in the myeloproliferative diseases. A raised serum vitamin $B_{12}$ seems to be found more commonly when there is a rise in transcobalamin I rather than transcobalamin III. It is of interest that in one of the patients who initially had a high serum vitamin $B_{12}$ level of $920 \mathrm{pg} / \mathrm{ml}$ (TBBC $5.01 \mathrm{ng} / \mathrm{ml}$ ) the serum vitamin $B_{12}$ level fell to $160 \mathrm{pg} / \mathrm{ml}$ (TBBC $1.56 \mathrm{ng} / \mathrm{ml}$ ) four months after starting treatment with azathioprine. In such a patient a high concentration of vitamin $\mathrm{B}_{12}$-binding proteins might mask vitamin $B_{12}$ deficiency as had been described in patients with chronic granulocytic leukaemia and concomitant pernicious anaemia (Britt and Rose, 1966; Corcino, Zalusky, Greenberg, and Herbert, 1971).

The raised levels of serum lysozyme may indicate an increased granulocyte turnover rate in patients with inflammatory bowel disease. Lysozyme appears to be released from dying granulocytes (Fink and Finch, 1968) and serum values have been shown by some workers (Hansen, 1973) but not by others (Levi, MacQueen, and Vincent, 1973) to correlate with granulocyte turnover rate in man. Other factors have to be considered. Serum lysozyme is raised in gross vitamin $\mathbf{B}_{12}$ or folate deficiency with megaloblastic anaemia probably due to ineffective leucopoiesis (Perillie, Kaplan, and Finch, 1967). In the present study none of the patients with raised lysozyme levels had a megaloblastic anaemia. Lysozyme is also released from monocytes and raised lysozyme levels have been noted in acute monocytic leukaemia (Osserman and Lawlor, 1966; Catovsky et al, 1971) and in active sarcoidosis (Pascual, Gee, and Finch, 1973). Thus, it is possible that excess lysozyme is released from monocytes in patients with inflammatory bowel disease. Monocytes are also known to secrete small amounts of TC I (Carmel and Coltman, 1971) but do not normally make a significant contribution to the serum UBBC (Chikkappa et al, 1971).

Whether granulocytes play an important primary role in the inflammatory process of Crohn's disease and ulcerative colitis or accumulate secondary to damage to the bowel by other processes remains uncertain. The present findings show, however, that the activity of the disease may be monitored by measurements of indices of granulocyte activity, the serum TBBC and serum lysozyme.

We should like to thank Mr J. Tilleray for technical assistance, and Miss Aviva Petrie for statistical advice.

\section{References}

Anderson, B. B. (1964). Investigations into the Euglena method for the assay of the vitamin $B_{12}$ in serum. J. clin. Path., 17, 14-26. Anthonisen, P., and Riis, P. (1962). The cytology of colonic secretion in proctosigmoidal disease. Acta med. scand., 172, 375-381.

Bloomfield, F. J., and Scott, J. M. (1972). Identification of a new vitamin $\mathbf{B}_{12}$ binder (Transcobalamin III) in normal human serum. Brit. J. Haemat., 22, 33-42. 
Bloomfield, F. J., Scott, J. M., Somerville, J. J. F., and Weir, D. G. (1973). Levels in normal, pathological, and foetal sera of the three transcobalamins. Irish J. med. Sci., 142, 51-57.

Britt, R. P., and Rose, D. P. (1966). Pernicious anemia with a normal serum vitamin $\mathbf{B}_{\mathbf{1 2}}$ level in a case of chronic granulocytic leukaemia. Arch. intern. Med., 117, 32-33.

Carmel, R. (1972a). Vitamin $B_{12}$-binding protein abnormality in subjects without myeloproliferative disease. I. Elevated serum vitamin $\mathbf{B}_{\mathbf{1 2}}$-binding capacity levels in patients with leucocytosis. Brit. J. Haemat., 22, 43-51.

Carmel, R. (1972b). Vitamin $\mathbf{B}_{12}$-binding protein abnormality in subjects without myeloproliferative disease. II. The presence of a third vitamin $B_{12}$-binding protein in serum. Brit. J. Haemat. 22, 53-62.

Carmel, R., and Coltman, C. A., Jr. (1971). Monocytic vitamin B $\mathbf{1 2}^{-}$ binding protein. Blood, 37, 360-366.

Carmel, R., and Herbert, V. (1972). Vitamin $B_{12}$-binding protein of leukocytes as a possible major source of the third vitamin $B_{12}$-binding protein of serum. Blood, 40, 542-549.

Catovsky, D., Galton, D. A. G., Griffin, C., Hoff brand, A. V., and Szur, L. (1971). Serum lysozyme and vitamin $\mathbf{B}_{12}$-binding capacity in myeloproliferative disorders. Brit. J. Haemat., 21, 661-672.

Chikkappa, G., Corcino, J., Greenberg, M. L., and Herbert, V. (1971). Correlation between various white blood cell pools and the serum $B_{12}$-binding capacities. Blood, 37, 142-151.

Corcino, J., Krauss, S. S., Waxman, S., and Herbert, V. (1970), Release of vitamin $\mathbf{B}_{12}$-binding protein by human leukocytes in vitro. J. clin. Invest., 49, 2250-2255.

Corcino, J. J., Zalusky, R., Greenberg, M., and Herbert, V. (1971). Coexistence of pernicious anaemia and chronic myeloid leukaemia; an experiment of nature involving vitamin $B_{12}$ metabolism. Brit. J. Haemat., 20, 511-520.
Fink, M. E., and Finch, S. C. (1968). Serum muramidase and granulocyte turnover. Proc. soc. exp. Biol. (N.Y.), 127, 365-367.

Gottlieb, C., Lau, K. S., Wasserman, L. R., and Herbert, V. (1965) Rapid charcoal assay for intrinsic factor (I.F.), gastric juice unsaturated $B_{12}$-binding capacity, antibody to I.F., and serum unsaturated $\mathrm{B}_{12}$-binding capacity. Blood, 25, 875-884.

Hansen, N. E. (1973). The relationship between the turnover rate of neutrophilic granulocytes and plasma lysozyme levels. Brit. J. Haemat., 25, 771-782.

Herbert, V. (1968). Diagnostic and prognostic values of measuremen of serum vitamin $B_{12}$-binding proteins. Blood, 32, 305-312.

Levi, J. A., MacQueen, A., and Vincent, P. C. (1973). Assessment of the value of lysozyme assay in neutropenia. Brit. J. Haemat. $25,757-770$.

Osserman, E. F., and Lawlor, D. P. (1966). Serum and urinary lysozyme (muramidase) in monocytic and monomyelocytic leukemia. J. exp. Med., 124, $921-951$.

Parry, R. M., Jr., Chandan, R. C., and Shahani, K. M. (1965). A rapid and sensitive assay for muramidase. Proc. Soc. exp. Biol. (N.Y.), 119, 384-386.

Pascual, R. S., Gee, J. B. L., and Finch, S. C. (1973). Usefulness of serum lysozyme measurement in diagnosis and evaluation of sarcoidosis. New Engl. J. Med., 289, 1074-1076.

Perillie, P. E., Kaplan, S. S., and Finch, S. C. (1967). Significance of changes in serum muramidase activity in megaloblastic anemia. New Engl. J. Med., 277, 10-12.

Riis, P., and Anthonisen, P. (1971). The presence of inflammatory leucocytes in the rectal mucus of patients with regional ileitis. Scand. J. Gastroent., 6, 719-721.

Silverstein, E., and Herbert, V. (1968). Rapid determination of vitamin $B_{12}$-binding $a$ and $\beta$ globulin in serum. Blood, 31, 518-521.

Zittoun, R., and Zittoun, J. (1973). Les transcobalamins. Nouv. Presse méd., 2, 919-924. 